\title{
ANALISIS KESALAHAN SISWA DALAM MENYELESAIKAN SOAL CERITA PROGRAM LINEAR SISWA KELAS X OTP 2 SMK NEGERI 1 LUBUKLINGGAU
}

\author{
Putri Mela Sari ${ }^{1}$, Idul Adha ${ }^{2}$, Efuansyah ${ }^{3}$ \\ ${ }^{1,2,3}$ Program Studi Pendidikan Matematika STKIP PGRI Lubuklinggau \\ Putrimelasari98@gmail.com ${ }^{1}$
}

\begin{abstract}
Abstrak
Penelitian ini bertujuan untuk mengetahui jenis-jenis kesalahan, faktor-faktor penyebab kesalahan serta solusi kesalahan yang dilakukan siswa dalam menyelesaikan soal cerita materi program linear. Metode penelitian yang digunakan deskriptif kualitatif. Teknik pengumpulan data dalam penelitian menggunakan tes, observasi, wawancara dan dokumentasi. Teknik analisis data dengan langkah-langkah: reduksi data, penyajian data, dan penarikan kesimpulan. Hasil penelitian menunjukan jenis-jenis kesalahan yang dilakukan siswa yaitu kesalahan konseptual (57\%), kesalahan prosedural (62\%), dan kesalahan komputasi (73\%). Berdasarkan hasil wawancara penyebab siswa melakukan kesalahan yaitu: Siswa tidak paham dengan maksud soal, siswa kurang cermat dan teliti dalam membaca soal, siswa kurang percaya diri dalam menjawab soal, siswa kurang memahami konsep dari program linear, siswa terburu-buru dalam menyelesaikan soal, dan siswa tidak terbiasa membuat kesimpulan akhir jawaban.
\end{abstract}

Kata Kunci: analisis kesalahan, soal cerita, program linear.

\begin{abstract}
This study aims to determine the types of error, the factors that cause errors, as well as solutions to errors carried out by student in solving linear program story problems. The research method used is descriptive qualitative.Data collection techniques in research using tests, observation, interviews and documentation. Data analysis techniques with steps: data reduction, data presentation, and drawing conclusions. The results showed the types of errors made by students, namely conceptual errors (57\%), procedural errors $(62 \%)$ and computation errors (73\%). Based on the results of the interview, the causes of the students made mistakes, namely: students do not understand the meaning of the question, students are not careful and careful in reading the questions, students lack confidence in answering questions, students do not understand the concept of linear programming, students rush to solve the problem, and students are not used to making final conclusions on answers.
\end{abstract}

Keywords: error analysis, story problems, linear programming

\section{PENDAHULUAN}

Matematika merupakan ilmu pengetahuan yang berkaitan dan mempunyai peranan penting dalam kehidupan seharihari (Adha \& Refianti, 2018). Pengaplikasian matematika dalam kehidupan sehari-hari dapat diterapkan dalam bentuk soal cerita. Soal cerita merupakan soal yang dibuat dalam bentuk cerita dan yang berkaitan dengan kehidupan sehari-hari. Dalam menyelesaikan soal cerita, siswa harus bisa memahami maksud dari soal cerita tersebut, mengetahui obyekobyek matematika yang harus diselesaikan, dan mampu membuat permisalannya ke dalam model matematika kemudian siswa harus mampu memilih operasi hitung dalam proses penyelesaiannya, hingga tahap akhir yaitu proses penarikan kesimpulan (Rahmawati dan Permata, 2018). Salah satu materi matematika yang berhubungan dengan soal cerita yaitu materi program linear. Program linear merupakan metode matematika yang bertujuan untuk mencapai suatu tujuan tunggal seperti memaksimumkan keuntungan atau meminimum keuntungan. Dalam memecahkan soal cerita program linear, siswa harus mampu mengubah soal ke dalam model matematika. Fakta dilapangan 
menunjukan bahwa siswa masih saja kesulitan dalam menyelesaikan soal cerita program linear. Rendahnya pemahaman siswa terhadap matematika adalah suatu masalah bagi mutu pendidikan dewasa ini dan akan berdampak terhadap prestasi belajar siswa. Prestasi belajar yang rendah merupakan salah satu bukti adanya kesulitan dalam belajar siswa. Menurut Efuansyah, dkk (2020) Belajar yang baik merupakan suatu kegiatan yang dapat memecahkan suatu masalah. Sesuai dengan pendapat Jamal (2014) bahwa kesulitan atau kendala belajar yang dialami siswa dapat disebabkan oleh faktor internal dan faktor eksternal. Faktor internal adalah faktor yang berasal dari dalam diri siswa, misalnya kesehatan, bakat, minat, motivasi dan sebagainya. Sedangkan, faktor eksternal merupakan faktor yang berasal dari luar diri siswa, misalnya lingkungan sekolah, lingkungan rumah, maupun lingkungan masyarakat. Berdasarkan hasil wawancara dengan guru. Pada tanggal 26 Juni 2020 diperoleh informasi bahwa prestasi belajar siswa masih kurang memuaskan pada materi program linear. Di SMK Negeri 1 Lubuklinggau khususnya kelas X OTP2, prestasi belajar matematika pada materi program linear masih sangat rendah. Hal ini ditunjukkan dari dokumentasi nilai rata-rata pada ulangan harian tahun ajaran 2019/2020 materi program linear kelas X OTP 2 hanya 57,14 dengan Kriteria Ketuntasan Minimal (KKM) 70. Ini berarti nilai rata-rata prestasi belajar matematika masih di bawah KKM. Siswa beraggapan bahwa mata pelajaran matematika itu sulit sehingga siswa kurang berminat untuk belajar matematika, serta pada saat guru menyampaikan materi pembelajaran banyak siswa yang gaduh dan kurang memperhatikan materi yang sedang disampaikan guru, sehingga berakibat seringkali siswa melakukan kesalahan dalam menyelesaikan soal yang diberikan.

Untuk mengatasi kesalahan tersebut perlu dilakukan analisis kesalahan siswa agar guru mengetahui kesalahan apa saja yang dilakukan oleh siswa dalam proses pembelajaran dan memperbaiki kesalahan yang dilakukan oleh siswa serta memilih cara atau strategi yang tepat agar siswa tidak melakukan kesalahan yang sama, sehingga siswa dapat mencapai hasil belajar yang diharapkan (Doren, dkk, 2019). Selain itu, guru dapat mengaitkan antara materi yang sedang dibahas dengan kondisi siswa, baik hobi siswa, kebutuhan siswa, ataupun lingkungan keseharian siswa agar pembelajaran berdampak positif dan juga menyenangkan. Menurut Wijaya dan Marsiyah (2013) jenis kesalahan yang berkaitan dengan matematika yaitu kesalahan konsep, kesalahan operasi dan kesalahan prinsip. Selain itu, menurut Irawati (2015) kesalahan dalam matematika dibagi menjadi dua yaitu kesalahan konseptual dan kesalahan prosedural

1) Kesalahan konseptual adalah kesalahan yang dilakukan siswa dalam menafsirkan fakta, konsep, dan prinsip. Adapun indikator kesalahannya:

a) Kesalahan dalam mengidentifikasi apa yang diketahui

b) Kesalahan dalam mengidentifikasi apa yang ditanyakan

c) Kesalahan dalam membuat model matematika

d) Kesalahan dalam penggunaan simbol

e) Kesalahan dalam membuat grafik

f) kesalahan dalam menentukan titik ektrim

2) Kesalahan prosedural adalah kesalahan dalam menyusun langkahlangkah yang hirarkis untuk menjawab suatu masalah. Adapun indikator kesalahannya:

a) Kesalahan dalam mengaplikasikan strategi untuk menyelesaikan suatu masalah

b) Kesalahan dalam melakukan operasi perhitungan

c) Kesalahan dalam menyimpulkan. Sedangkan menurut Sulistyowati dan Sujadi (2015) jenis kesalahan yang dilakukan siswa dalam menyelesaikan soal matematika yaitu kesalahan pemahaman soal, kesalahan penerapan 
konsep dan prinsip matematika serta kesalahan komputasi.

Berdasarkan pendapat para ahli tersebut dapat disimpulkan mengenai jenis-jenis kesalahan siswa dalam menyelesaikan soal matematika adalah kesalahan konseptual, prosedural dan komputasi (perhitungan). Indikator dari kesalahan tersebut dapat dilihat pada tabel 1 berikut:

Tabel 1. Jenis dan Indikator Kesalahan Siswa

\begin{tabular}{|l|l|}
\hline \multicolumn{1}{|c|}{$\begin{array}{c}\text { Kesalahan pada } \\
\text { langkah }\end{array}$} & \multicolumn{1}{c|}{ Indikator } \\
\hline Konseptual & $\begin{array}{l}\text { 1. Kesalahan dalam menuliskan apa yang diketahui dan apa yang } \\
\text { ditanyakan. }\end{array}$ \\
& $\begin{array}{l}\text { 2. Kesalahan dalam membuat model matematika. } \\
\text { 3. Kesalahan dalam memilih simbol. }\end{array}$ \\
& $\begin{array}{l}\text { 4. Kesalahan dalam membuat grafik penyelesaian. } \\
\text { 5. Kesalahan dalam menentukan titik optimum. } \\
\text { 6esalahan dalam menentukan fungsi objektif. }\end{array}$ \\
& $\begin{array}{l}\text { 7. Kesalahan dalam menentukan nilai optimum. } \\
\text { 1. Kesalahan dalam menyusun langkah-langkah menyelesaikan } \\
\text { soal }\end{array}$ \\
\hline $\begin{array}{l}\text { Komputasi } \\
\text { (perhitungan) }\end{array}$ & $\begin{array}{l}\text { 1. Kesalahan dalam melakukan proses perhitungan. } \\
\text { 2. Kesalahan dalam menyimpulkan. }\end{array}$ \\
\hline
\end{tabular}

Menurut Farida (2015) penyebab kesalahan yang dilakukan siswa dalam menyelesaikan soal matematika yaitu: 1) Tidak paham konsep-konsep sederhana 2) Tidak mengetahui maksud soal, 3) Tidak bisa menerjemahkan soal ke dalam kalimat matematika, 4) Tidak bisa menyelesaikan kalimat matematika, 5) Tidak cermat dalam menghitung, 6) Kesalahan dalam menulis angka. Faktor lain yang menyebabkan kesalahan siswa adalah kurangnya pengetahuan dan keterampilan dalam mengubah kalimat verbal ke kalimat matematika, kurangnya ketelitian dalam membaca, tidak memahami maksud dari soal, kurangnya siswa dalam menangkap informasi masalah yang terkandung dalam soal, lupa, kurangnya latihan mengerjakan soal-soal program linier yang variatif (Zaidy dan Lutfianto, 2016). Sedangkan menurut Amilia dan Yarman (2019) penyebab kesalahan yang dilakukan siswa adalah tidak terampil menggunakan rumus, kurang teliti, dan kebiasaan peserta didik yang tidak mengulang pelajaran. Berdasarkan pendapat para ahli di atas dapat disimpulkan bahwa faktor-faktor penyebab kesalahan siswa dalam menyelesaikan soal matematika adalah siswa tidak paham konsep-konsep sederhana, siswa tidak memahami maksud soal, siswa tidak bisa menerjemahkan soal ke dalam kalimat matematika, serta siswa tidak teliti dalam membaca soal.

Penelitian yang dilakukan oleh Fatahillah, Wati, \& Susanto (2017) berjudul: "Analisis Kesalahan Siswa dalam Menyelesaikan Soal Cerita Matematika Berdasarkan Tahapan Newman Beserta Bentuk Scaffolding yang Diberikan". Jenis penelitian ini adalah penelitian deskriptif dengan pendekatan kualitatif. Dari kesalahankesalahan yang dilakukan siswa, persentase kesalahan paling tinggi adalah kesalahan memahami masalah yaitu sebesar 69,24\%, sedangkan persentase kesalahan paling rendah adalah kesalahan membaca yaitu sebesar $23,12 \%$.

Prestasi belajar matematika siswa Kelas X SMK Negeri 1 Lubukliggau masih tergolong rendah. Karena, di lihat dari dokumentasi nilai rata-rata pada ulangan harian tahun ajaran 2019/2020 materi program linear hanya $57,14 \%$.

Hal ini kemudian menjadi pendorong bagi peneliti untuk mengadakan penelitian 
tentang analisis kesalahan siswa dalam menyelesaikan soal cerita program linier. Sehingga tujuan dari penelitian ini adalah:

1. Untuk mengetahui jenis kesalahan siswa kelas $\mathrm{X}$ OTP 2 SMK Negeri 1 Lubuklinggau dalam menyelesaikan soal cerita materi Program Linear,

2. Untuk mengetahui faktor-faktor penyebab kesalahan siswa kelas X OTP 2 SMK Negeri 1 Lubuklinggau dalam menyelesaikan soal cerita materi Program Linear,

3. Untuk mengetahui solusi terhadap kesalahan yang dilakukan siswa kelas $\mathrm{X}$ OTP 2 SMK Negeri 1 Lubuklinggau dalam menyelesaikan soal cerita materi Program Linear.

\section{METODE}

Ditinjau dari judul penelitian maka metode penelitian yang digunakan dalam penelitian ini adalah penelitian deskriptif dengan pendekatan kualitatif. Menurut Sugiyono (2017) metode penelitian kulitatif sering disebut metode penelitian naturalistik karena penelitiannya dilakukan pada kondisi yang alamiah (natural setting); disebut juga sebagai metode etnographi, karena pada awalnya metode ini lebih banyak digunakan untuk penelitian bidang antropologi budaya; disebut sebagai metode kualitatif, karena data yang terkumpul dan analisisnya lebih bersifat kualitatif. Pelitian kualitatif menekankan pada makna, penalaran, definisi suatu situasi tertentu (dalam konteks tertentu), serta lebih banyak meneliti hal-hal yang berhubungan dengan kehidupan sehari-hari. Penelitian ini bertujuan untuk mengetahui jenis-jenis kesalahan dan faktor-faktor penyebab kesalahan yang dilakukan siswa dalam menyelesaikan soal cerita materi program linear. Tempat penelitian adalah Sekolah Menengah Kejuruan (SMK) Negeri 1 Lubuklinggau. SMK Negeri 1 Lubuklinggau terletak di Jl. Jendral A. Yani No. 84, Jogoboyo, Kec. Lubuklinggau Utara II, kota Lubuklinggau. Penelitian dilakukan di kelas X OTP 2 tahun pelajaran 2019/2020, pemilihan kelas ini didasarkan beberapa pertimbangan, antara lain karena kelas X OTP 2 tahun pelajaran 2019/2020 cukup mengalami permasalahan dalam menyelesaikan soal cerita terutama pada materi program linear. Subjek dalam penelitian ini, yaitu siswa yang telah mempelajari materi program linear, yaitu kelas X OTP 2. Jumlah siswa nya ada 35 orang, diantaranya 12 siswa laki-laki dan 23 siswa perempuan.

Prosedur penelitian ini dilakukan dengan pertama-tama menyiapkan instrumen soal tes materi program linear sebanyak 4 butir soal. Sebelum soal tes diberikan kepada siswa soal tes di validasi terlebih dahulu. Setelah selesai di validasi soal tes diberikan kepada siswa, selanjutnya peneliti mendapatkan data dari jawaban siswa, lalu peneliti memilih 6 orang siswa yang melakukan kesalahan saat menyelesaikan soal cerita materi program linear, 6 orang siswa tersebut dipilih berdasarkan kategori kelompok atas, kelompok sedang dan kelompok bawah. Selanjutnya peneliti melakukan wawancara khusus untuk 6 orang siswa terpilih sebagai subjek penelitian. Sumber data dalam penelitian dapat dikategorikan menjadi dua yakni sumber primer dan sumber sekunder. Sumber primer adalah sumber data yang diperoleh langsung dari hasil penelitian, seperti observasi dan wawancara yang dilakukan di SMK Negeri 1 Lubuklinggau. Sedangkan sumber sekunder adalah sumber data yang diperoleh dari berbagai literatur, seperti buku dan jurnal yang berhubungan dengan penelitian ini.

Adapun teknik dan prosedur penelitian yang digunakan peneliti adalah observasi, wawancara dan dokumentasi. Observasi yang dilakukan pada penelitian ini adalah peneliti mengobservasi hasil jawaban siswa dalam menyelesaikan soal cerita materi program linear. Dalam penelitian ini, peneliti melakukan wawancara tak terstruktur kepada guru ketika peneliti melakukan studi pendahuluan dan kepada 6 subjek penelitian, subjek dipilih berdasarkan hasil analisis siswa, 6 subjek ini mewakili siswa yang melakukan kesalahan-kesalahan yang akan peneliti kaji. Wawancara dilakukan setelah siswa mengerjakan soal cerita program linear dan setelah peneliti melakukan observasi pada 
semua jawaban siswa, wawancara dilakukan di luar waktu pembelajaran. Wawancara dalam penelitian ini digunakan untuk mengetahui faktor-faktor penyebab siswa melakukan kesalahan dalam menyelesaikan soal cerita program linear. Dokumentasi dalam penelitian ini yaitu berupa catatan siswa.

Kemudian prosedur analisis data dilakukan dengan tahap sebagai berikut:

\section{Data Reduction(Reduksi Data)}

Mereduksi data berarti merangkum, memilih hal-hal yang pokok, memfokuskan pada hal-hal yang penting, dicari tema dan polanya dan membuang yang tidak perlu. Dengan demikian data yang telah direduksi dapat memberikan gambaran yang lebih jelas, dan akan mempermudah peneliti dalam melakukan pengumpulan data selanjutnya, dan mencarinya bila diperlukan.

Tahap-tahap reduksi dalam penelitian ini adalah:

a. Mengoreksi hasil jawaban siswa, kemudian diranking untuk menentukan siswa yang akan dijadikan subjek penelitian

b. Hasil jawaban siswa yang dipilih menjadi subjek penelitian merupakan bahan untuk wawancara. Tujuannya untuk mengetahui faktor-faktor penyebab siswa melakukan kesalahan dalam menyelesaikan soal cerita program linear.

2. Data Display (Penyajian Data)

Penyajian data adalah sekumpulan informasi tersusun yang memberi kemungkinan penarikan kesimpulan dan pengambilan tindakan.

\section{Conclusion}

Drawing/Verification(Penarikan

Kesimpulan)

Kesimpulan dalam penelitian kualitatif ini diharapkan adalah merupakan temuan baru yang sebelumnya belum pernah ada. Menarik kesimpulan dan verifikasi adalah sebagian dari suatu kegiatan dari konfigurasi yang utuh sehingga mampu menjawab pertanyaan penelitian dan tujuan penelitian.

Analisis kesalahan-kesalahan siswa dilakukan dengan melihat jawaban dan mengidentifikasinya sesuai dengan indikator kesalahan siswa. Skor jawaban yang didapatkan kemudian dikelompokkan berdasarkan jenis kesalahan jenis kesalahan siswa sesuai dengan kunci jawaban dari 4 butir soal. Pemberian skor jawaban merujuk pada (Aly, Sujadi, dan Taufik, 2019) dimana jawaban yang benar pada masingmasing tahapan akan diberikan skor 0 sedangkan jawaban yang salah akan diberikan skor 1. Untuk menghitung besarnya persentase kesalahan yang dilakukan oleh siswa pada tiap-tiap jenis kesalahan dengan menggunakan rumus berikut:

$$
\mathrm{P}_{i}=\frac{n_{l}}{N} x 100 \%
$$

dimana:

$$
\begin{aligned}
& \mathrm{P}_{i}=\begin{array}{l}
\text { Persentase masing-masing kategori } \\
\text { kesalahan, }
\end{array} \\
& n_{l}=\begin{array}{c}
\text { Banyaknya kesalahan untuk masing- } \\
\text { masing kategori kesalahan, }
\end{array} \\
& \mathrm{N}=\begin{array}{c}
\text { Banyaknya kesalahan untuk seluruh } \\
\text { kategori kesalahan. }
\end{array}
\end{aligned}
$$

Setelah persentase dihitung, kemudian persentase kesalahan siswa tersebut dapat dikategorikan pada tabel 2 berikut:

Tabel 2. Klasifikasi Persentase Setiap Jenis Kesalahan

\begin{tabular}{|c|c|}
\hline Persentase & Kategori \\
\hline $0 \% \leq \mathrm{P}<20 \%$ & Sangat rendah \\
\hline $20 \% \leq \mathrm{P}<40 \%$ & Rendah \\
\hline $40 \% \leq \mathrm{P}<60 \%$ & Sedang \\
\hline $60 \% \leq \mathrm{P}<80 \%$ & Tinggi \\
\hline $80 \% \leq \mathrm{P}<100 \%$ & Sangat tinggi \\
\hline
\end{tabular}

Penelitian ini menggunakan uji keabsahan melalui triangulasi teknik.
Tujuan dari teknik triangulasi ini adalah untuk membandingkan data dari sumber 
yang sama dengan teknik yang berbeda. Triangulasi teknik dilakukan untuk membandingkan informasi yang diperoleh dari hasil tes dengan wawancara pada peserta didik. Pada penelitian ini, uji ini menggunakan teknik triangulasi dengan cara mengecek data kepada sumber yang sama namun dengan teknik yang berbeda yakni observasi, wawancara guru dan wawancara beberapa siwa sebagai subjek penelitian dan dokumentasi. Observasi analisis hasil jawaban siswa dilakukan setelah siswa menjawab soal cerita materi program linear, wawancara guru dilakukan pada studi pendahuluan, sedangkan wawancara kepada beberapa siswa dilakukan setelah peneliti mengobservasi dan menganalisis hasil jawaban siswa. Dokumentasi dalam penelitian ini berupa catatan siswa.

\section{HASIL PENELITIAN DAN PEMBAHASAN}

Analisis kesalahan siswa pada soal nomor 1

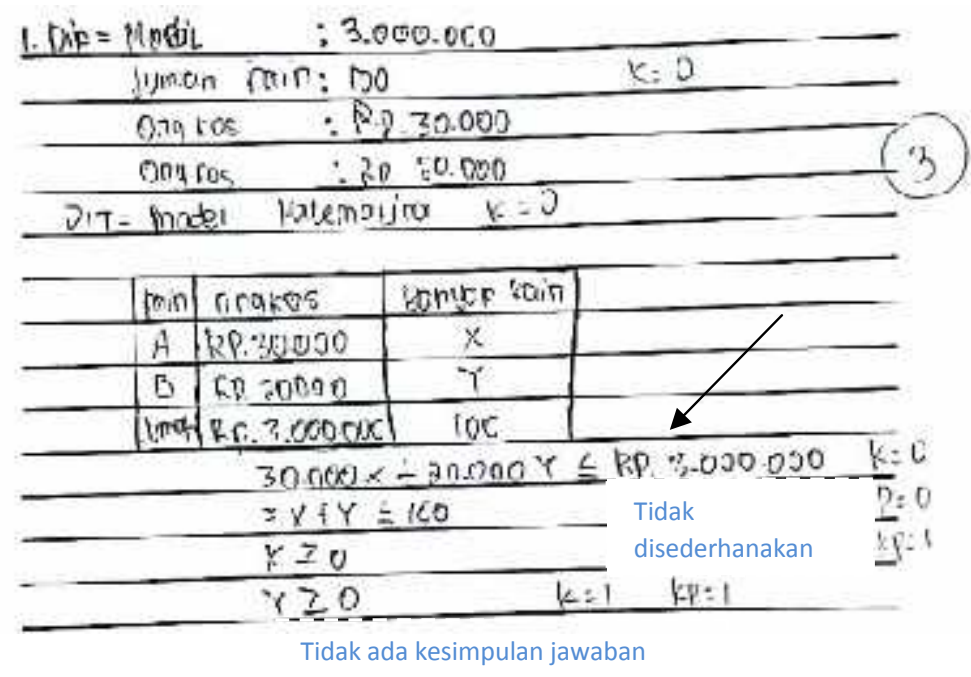

Gambar 1. Lembar Jawaban S-13

\section{Analisis I}

Dari analisis data yang dilakukan dapat dilihat bahwa siswa S-13 mengalami kesalahan pada tahap konseptual dan komputasi. Dapat dilihat pada gambar di atas, siswa S-13 tidak menyederhanakan pertidaksamaan yang telah dibuat dan siswa tidak membuat kesimpulan akhir jawaban.

\section{Analisis II}

Berdasarkan hasil wawancara dengan siswa S-13 diperoleh hasil reduksi data bahwa siswa tidak menyederhanakan pertidaksamaan linearnya, seharusnya $30.000 x+20.000 y \leq 3.000 .000$ bisa disederhanakan menjadi $3 \mathrm{x}+2 \mathrm{y} \leq 300$. Dan siswa tidak menuliskan sama sekali kesimpulan jawaban dari soal.

\section{Analisis kesalahan siswa pada soal nomor 2}




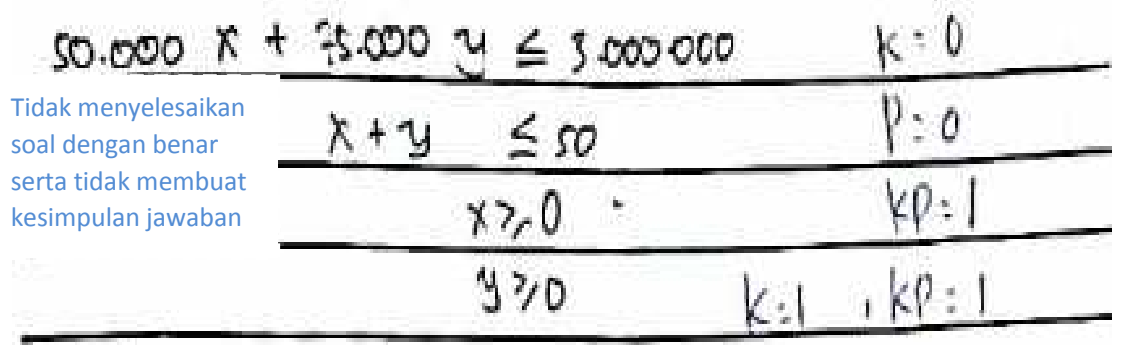

Gambar 2. Lembar Jawaban S-18

\section{Analisis I}

Dari analisis data yang dilakukan dapat dilihat bahwa siswa S-18 mengalami kesalahan pada tahap konseptual dan tahap komputasi. Dapat dilihat pada gambar di atas, siswa S-18 tidak menyederhanakan pertidaksamaan yang telah dibuat dan tidak membuat kesimpulan akhir jawaban.

\section{Analisis II}

Berdasarkan hasil wawancara dengan siswa S-18 diperoleh hasil reduksi data bahwa siswa tidak menyederhanakan pertidaksamaan linearnya, seharusnya dari pertidaksamaan 50.000x $+75.000 \mathrm{y} \leq$ 3.000 .000 bisa disederhanakan menjadi $2 \mathrm{x}$ $+3 y \leq 120$. Alasannya tidak menyederhanakan karena dia terburu-buru dalam menyelesaikan soal tersebut. Dan siswa tidak menuliskan sama sekali kesimpulan jawaban dari soal.

Analisis kesalahan siswa pada soal nomor 3

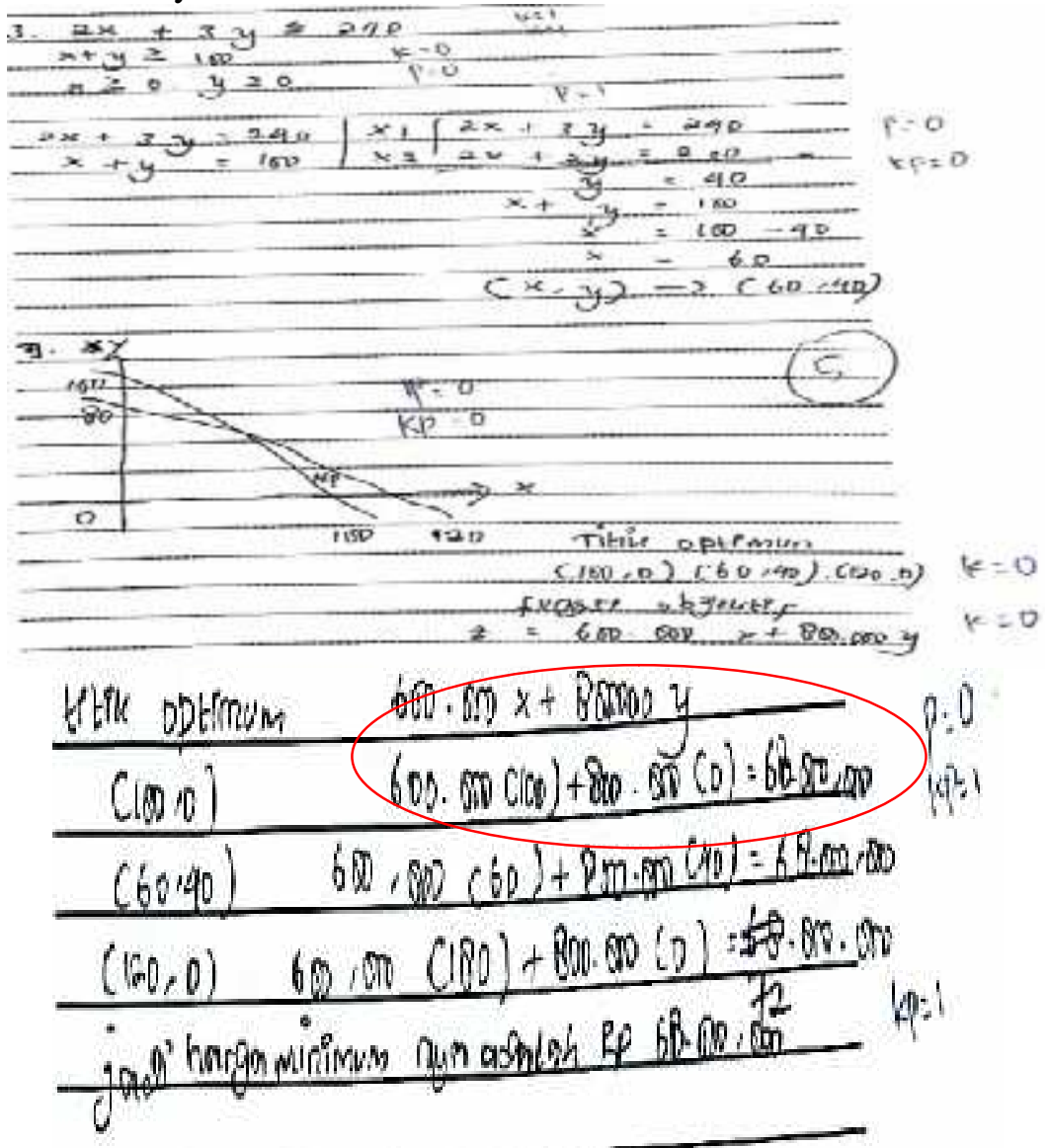

Gambar 3. Lembar Jawaban S-7 


\section{Analisis I}

Dari analisis data yang dilakukan dapat dilihat bahwa siswa S-7 mengalami kesalahan pada tahap konseptual dan tahap komputasi. Dapat dilihat pada gambar di atas, siswa S-7 tidak menuliskan apa yang diketahui dan apa yang ditanyakan pada soal dan siswa S-7 melakukan kesalahan pada proses perhitungan titik optimum, sehingga kesimpulan yang telah di buat juga salah.

\section{Analisis II}

Berdasarkan hasil wawancara dengan siswa S-7 diperoleh hasil reduksi data bahwa siswa mengalami kesalahan pada langkah konseptual dan procedural. Siswa tidak menuliskan apa yang diketahui dan apa yang ditanyakan pada soal. Siswa salah pada saat menjumlahkan $600.000(100)+$ $800.000(0)=68.000 .000$. Hal tersebut disebabkan karena siswa terburu-buru mengerjakan penyelesaiannya. Sehingga kesimpulan nya juga salah.

\section{Analisis kesalahan siswa pada soal nomor 4}

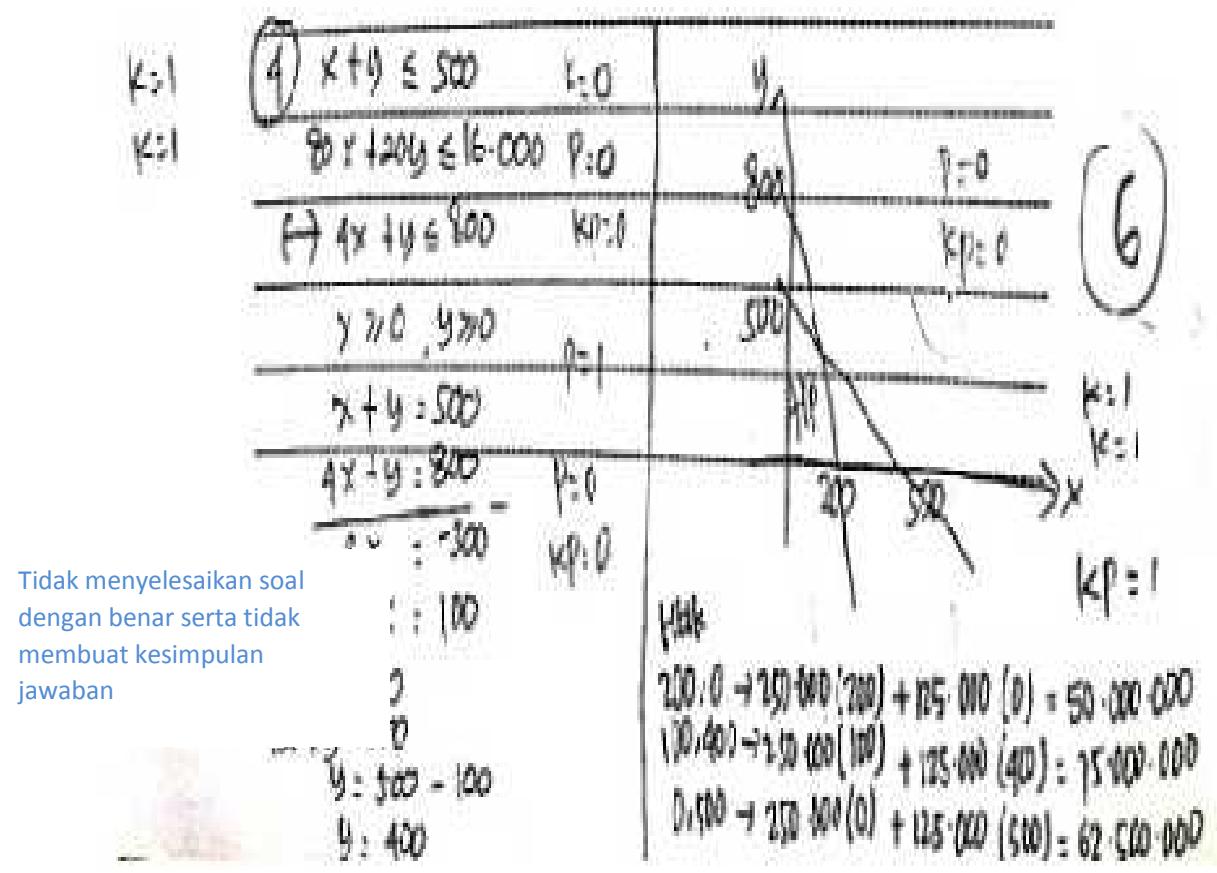

Gambar 4. Lembar Jawaban S-10

\section{Analisis I}

Dari analisis data yang dilakukan dapat dilihat bahwa siswa S-10 mengalami kesalahan pada tahap konseptual, prosedural dan komputasi. Dapat dilihat pada gambar di atas, siswa S-10 tidak menuliskan apa yang diketahui dan apa yang ditanyakan pada soal, siswa tidak dapat menyelesaikan soal dengan benar serta siswa S-10 tidak membuat kesimpulan akhir jawaban.

\section{Analisis II}

Berdasarkan hasil wawancara dengan siswa S-10 diperoleh hasil reduksi data bahwa siswa S-10 melakukan kesalahan pada tahap konseptual, prosedural dan komputasi. Pada gambar di atas, dapat dilihat bahwa siswa tidak menuliskan apa yang diketahui dan apa yang ditanyakan pada soal, siswa tidak dapat menyelesaikan soal sampai selesai, sehingga siswa tidak membuat kesimpulan akhir jawaban.

Jenis-jenis kesalahan yang dilakukan siswa dalam menyelesaikan soal cerita program linear yaitu kesalahan konseptual, kesalahan prosedural, dan kesalahan komputasi.

a. Kesalahan Konseptual

Kesalahan pada tahap ini yaitu kesalahan dalam menuliskan apa yang diketahui dan apa yang ditanyakan, 
kesalahan dalam membuat model matematika, kesalahan dalam memilih simbol, kesalahan dalam membuat grafik, kesalahan dalam menentukan titik optimum, kesalahan dalam menentukan fungsi objektif, serta kesalahan dalam menentukan nilai optimum. Rata-rata kesalahan siswa pada tahap konseptual adalah 57\%.

b. Kesalahan Prosedural

Kesalahan pada tahap ini yaitu kesalahan dalam menyusun langkahlangkah menyelesaikan soal. Rata-rata kesalahan siswa pada tahap prosedural adalah $62 \%$.

c. Kesalahan Komputasi

Kesalahan pada tahap ini yaitu kesalahan dalam melakukan proses perhitungan dan kesalahan dalam menyimpulkan kesimpulan akhir jawaban. Rata-rata kesalahan siswa pada tahap komputasi adalah $73 \%$.

Berikut adalah tabel 3 persentase jenisjenis kesalahan yang dilakukan siswa dalam menyelesaikan soal cerita program linear, yaitu:

Tabel 3. Persentase Jenis-jenis Kesalahan

\begin{tabular}{|c|c|c|c|c|c|c|}
\hline \multirow{2}{*}{$\begin{array}{c}\text { Jenis } \\
\text { kesalahan }\end{array}$} & \multirow{2}{*}{$\Sigma$} & \multicolumn{4}{|c|}{ NOMOR SOAL } & \multirow[t]{2}{*}{ Total } \\
\hline & & 1 & 2 & 3 & 4 & \\
\hline \multirow{4}{*}{ Konseptual } & $\Sigma \mathrm{B}$ & 62 & 57 & 54 & 41 & \multirow{4}{*}{$57 \%$} \\
\hline & $\Sigma \mathrm{S}$ & 38 & 43 & 96 & 109 & \\
\hline & $\Sigma \mathrm{B}+\Sigma \mathrm{S}$ & 100 & 100 & 150 & 150 & \\
\hline & Persentase & $38 \%$ & $43 \%$ & $64 \%$ & $72,66 \%$ & \\
\hline \multirow{4}{*}{ Prosedural } & $\Sigma \mathrm{B}$ & 25 & 16 & 35 & 37 & \multirow{4}{*}{$62 \%$} \\
\hline & $\Sigma \mathrm{S}$ & 0 & 9 & 90 & 88 & \\
\hline & $\Sigma \mathrm{B}+\Sigma \mathrm{S}$ & 25 & 25 & 125 & 125 & \\
\hline & Persentase & $0 \%$ & $36 \%$ & $72 \%$ & $70,4 \%$ & \\
\hline \multirow{4}{*}{ Komputasi } & $\Sigma \mathrm{B}$ & 23 & 13 & 14 & 25 & \multirow{4}{*}{$73 \%$} \\
\hline & $\Sigma \mathrm{S}$ & 27 & 37 & 61 & 75 & \\
\hline & $\Sigma \mathrm{B}+\Sigma \mathrm{S}$ & 50 & 50 & 75 & 100 & \\
\hline & Persentase & $54 \%$ & $74 \%$ & $81,33 \%$ & $75 \%$ & \\
\hline
\end{tabular}

Keterangan:

$\begin{array}{ll}\Sigma \mathrm{B} & =\text { Jumlah Benar } \\ \Sigma \mathrm{S} & =\text { Jumlah Salah }\end{array}$

Adapun persentase kesalahan yang dilakukan siswa pada tiap butir soal adalah sebagai berikut:

\section{a. Soal nomor 1}

Pada soal nomor 1, siswa yang melakukan kesalahan pada tahap konseptual sebesar (38\%), pada tahap prosedural kesalahan yang dilakukan siswa sebesar (0\%), sedangkan pada tahap komputasi kesalahan yang dilakukan siswa sebesar $(54 \%)$.

b. Soal nomor 2

Pada soal nomor 2, siswa yang melakukan kesalahan pada tahap konseptual sebesar (43\%), pada tahap prosedural kesalahan yang dilakukan siswa sebesar
(36\%), sedangkan pada tahap komputasi kesalahan yang dilakukan siswa sebesar (74\%).

c. Soal nomor 3

Pada soal nomor 3, siswa yang melakukan kesalahan pada tahap konseptual sebesar (64\%), pada tahap prosedural kesalahan yang dilakukan siswa sebesar (72\%), sedangkan pada tahap komputasi kesalahan yang dilakukan siswa sebesar $(81 \%)$.

d. Soal nomor 4

Pada soal nomor 4, siswa yang melakukan kesalahan pada tahap konseptual sebesar $(73 \%)$, pada tahap prosedural kesalahan yang dilakukan siswa sebesar 
(70\%), sedangkan pada tahap komputasi kesalahan yang dilakukan siswa sebesar $(75 \%)$.

\section{SIMPULAN}

Berdasarkan pembahasan diperoleh kesimpulan sebagai berikut:

1. Jenis-jenis Kesalahan yang Dilakukan Siswa

Kesalahan konseptual, Kesalahan pada tahap ini yaitu kesalahan dalam menuliskan apa yang diketahui dan apa yang ditanyakan, kesalahan dalam membuat model matematika, kesalahan dalam memilih simbol, kesalahan dalam membuat grafik, kesalahan dalam menentukan titik optimum, kesalahan dalam menentukan fungsi objektif, serta kesalahan dalam menentukan nilai optimum. Rata-rata kesalahan siswa pada tahap konseptual adalah 57\%. Kesalahan prosedural, Kesalahan pada tahap ini yaitu kesalahan dalam menyusun langkah-langkah menyelesaikan soal. Rata-rata kesalahan siswa pada tahap prosedural adalah $62 \%$. Kesalahan komputasi, Kesalahan pada tahap ini yaitu kesalahan dalam melakukan proses per hitungan dan kesalahan dalam menyimpulkan kesimpulan akhir jawaban. Rata-rata kesalahan siswa pada tahap komputasi adalah $73 \%$.

2. Faktor-faktor Penyebab Kesalahan yang Dilakukan Siswa

Faktor-faktor penyebab kesalahan yang dilakukan siswa dalam menyelesaikan soal cerita program linear adalah sebagai berikut: Konseptual, Penyebab siswa melakukan kesalahan pada langkah konseptual ini adalah siswa tidak paham dengan maksud soal, siswa kurang cermat dan teliti dalam membaca soal, siswa kurang memahami konsep dari program linear, siswa tidak paham dengan simbol yang digunakan. Prosedural, Penyebab siswa melakukan kesalahan pada langkah prosedural ini adalah siswa kurang percaya diri dalam menjawab soal, siswa terburuburu dalam menyelesaikan soal, siswa tidak mengetahui langkah penyelesaian soal. Komputasi, Penyebab siswa melakukan kesalahan pada langkah komputasi ini adalah siswa terburu-buru dalam menyelesaikan soal, siswa menganggap penyelesaian yang ditulis sudah benar, siswa tidak terbiasa membuat kesimpulan akhir jawaban.

Berdasarkan kesimpulan pada penelitian ini, disarankan sebagai berikut:

1. Kepada Guru

Dalam rangka mengurangi banyaknya kesalahan yang dilakukan siswa yang disebabkan oleh kurangnya pemahaman siswa dalam memahami konsep yang telah diberikan seperti penggunaan rumus yang tidak tepat, maka guru perlu menekankan pemahaman konsep secara jelas dalam pembelajaran matematika khususnya materi program linear. Serta memberikan motivasi kepada siswa agar menyampaikan kesulitan yang dialami ketika kegiatan belajar mengajar.

2. Kepada Siswa

Siswa hendaknya menyampaikan kesulitan-kesulitan yang dialami kepada guru. Bagi siswa yang melakukan kesalahan hendaknya banyak berlatih dalam menyelesaikan berbagai macam variasi soal cerita untuk melatih memahami maksud soal cerita dan cara penyelesaiannya dan siswa harus lebih teliti dalam menyelesaikan soal.

\section{REFERENSI}

Adha, I \& Refianti, R. (2018). Missouri Mathematics Project Berbasis Soal Open Ended terhadap Kemampuan Komunikasi Matematika. Jurnal Pendidikan Matematika, 1 (2), 135-143.

Aly, B.F.N., Sujadi, AA., \& Taufik, I. (2019). Analisis Kesalahan dalam Menyelesaikan Soal Matematika Pada Kelas X SMK Negeri 1 Seyegan. Jurnal Pendidikan Matematika. 7 (1), 135-144.

Amilia, Dwi Putri \& Yarman (2019). Analisis Kesalahan Peserta Didik Kelas VII SMP N 22 Padang dalam Menyelesaikan Soal-Soal Matematika Berdasarkan Taksonomi Solo. Jurnal Edukasi dan Penelitian Matematika. 8 (2), 11-17.

Doren, A.P.N., Sumadji, \& Farida, N. (2019). Analisis Kesalahan Siswa dalam Menyelesaikan Soal Cerita Matematika Berdasarkan Tahapan Penyelesaian Polya. Seminar Nasional FST 2019, 2, 670-677. 
Efuansyah., Wahyuni, R., Friansah, D \& Wulandari, T.A. (2020). Model Learning Cycle 5E terhadap Kemampuan Pemecahan Masalah Matematika. Jurnal Pendidikan Matematika RAFA. 6 (1), 54-62.

Farida, N. (2015). Analisis Kesalahan Siswa SMP Kelas VIII Dalam Menyelesaikan Masalah Soal Cerita Matematika. Jurnal Pendidikan Matematika, 4 (2), 42-52.

Fatahillah, A., Wati, Y.F., \& Susanto. (2017). Analisis Kesalahan Siswa dalam Menyelesaikan Soal Cerita Matematika Berdasarkan Tahapan Newman Beserta Bentuk Scaffolding yang Diberikan. Kadikma, 8 (1), 4051.

Hamzah, A. (2014). Evaluasi Pembelajaran Matematika. Jakarta: Raja Grafindo Persada.

Irawati, S. (2015). Analisis Kesalahan Mahasiswa Calon Guru Matematika dalam Memecahkan Masalah Program Linear. Sigma. 1 (1), 29-34.

Jamal, F. (2014). Analisis Kesulitan Belajar Siswa dalam Pelajaran Matematika Pada Materi Peluang Kelas XI IPA SMA
Muhammadiyah Muelaboh Johan Pahlawan. Jurnal MAJU, 1 (1), 18-36.

Rahmawati, D \& Permata, L.D. (2018). Analisis Kesalahan Siswa dalam Menyelesaikan Soal Cerita Program Linear dengan Prosedur Newman. Jurnal Elektronik Pembelajaran Matematika. 5 (2), 173-185.

Sugiyono. (2017). Metode Penelitian Pendidikan Pendekatan Kuantitatif, Kualitatif, dan R\&D. Bandung: ALPABETA, cv.

Sulistyowati, A., \& Sujadi, A.A. (2015). Analisis Kesalahan dalam Menyelesaikan Soal, Sudut, Luas, dan keliling Segitiga Siswa Kelas VII SMP Negeri 2 Melati, Sleman. Jurnal Pendidikan Matematika, 3 (3), 265-274.

Wijaya, A. A., \& Masriyah (2013). Analisis Kesalahan Siswa dalam Menyelesaikan Soal Cerita Materi SPLDV. E-journal UNESA, 2 (1), 1-8.

Zaidy, F \& Lutfianto, M. (2016). Analisis Kesalahan Siswa SMK dalam Menyelesaikan Soal Program Linier Berdasarkan NEWMAN'S ERROR ANALYSIS (NEA) Ditinjau Dari Kemampuan Matematika. Seminar Nasional Pendidikan Matematika Ahmad Dahlan, 297-303. 